\title{
"No Lion can him Fright”
}

\author{
Douglas Bennett
}

On 31 December 1992 Ben Silcock, a 27-yearold man, climbed into the lion's den at London Zoo where he was mauled by a lion. In the newspaper accounts it was evident that he suffered from schizophrenia. His father Bryan Silcock added that "he would sit up in his room smoking dope". One national newspaper asked why people like Ben were not in hospital and his father blamed the health authorities for letting his son down.

Since that time Marjorie Wallace has reported (The Times 31 December 1993) that Ben Silcock climbed into the lion's den at London Zoo carrying two frozen turkeys to share with them. He was said to have a spiritual affinity with animals, especially big cats, and felt that he had a mission to relieve their suffering. He saw them as victims of man's oppression and said, after admission to hospital, that "he had to test himself against the reality of nature". According to Ms Wallace, he was being treated in 1993 in Bethlem Royal Hospital, where he had been admitted after wounding two police officers with a Stanley knife.

I was not entirely surprised by the press's indignant complaints that this unfortunate event was the result of the inadequate implementation of community care policies. Yet my dissatisfaction with this superficial analysis led me to think that it might be helpful to put Ben Silcock's sad experience into perspective by considering similar incidents reported in the press of other countries (with or without community care) which had not been reported here and hence were not widely known. No independent medical or psychiatric views are included.

The second incident occurred in Germany in the Berlin Zoo on 24 September 1992. The Berliner Zeitung (25 September 1992) reported that a 28-year-old woman, Gabrielle H, stood with her sons Benjamin (9) and Oliver (8) in front of the tiger's enclosure. A witness heard her say that she wanted to prove to her children that the tiger would not harm her since she could influence the animal (which was only a big cat) by telepathy. So she climbed on to the railings, hung on to an overhanging branch and dropped into the moat which separated the tigers from the visitors. As she stood in the water of the moat, the tiger hit her and rolled her up and down using its right forepaw. A visitor shouted for help and a keeper pulled her to safety. She was taken to hospital with a chest wound and grazes and later transferred to a psychiatric unit where she showed symptoms of schizophrenia.

The third incident was reported in the New York Times (6 May 1993). A 32-year-old man had climbed into the lion's den at Bronx Zoo. He was said to be suffering from schizophrenia. He had jumped over a 2 metre fence, scrambled 4 metres to the top of the animal holding area, then climbed another 4 metres to a fence at the top of the building. To reach the lion's area he had to climb or drop as much as 6 metres. He only suffered scratches to his face and scalp. The zoo staff prevented more serious injury by instructing him to remain still in the foetal position and by luring the lions into the holding area.

The fourth incident occurred in 1971 in the Netherlands when a 41-year-old man having tried to get into the lion's area in a safari park had been stopped by the keepers but was later found in the lion's den in Trlburg Zoo. He had been killed either by the lions or by dropping 5 metres into their den. The incident was not witnessed but he had surmounted a fence of barbed wire. The Nieuwsblad van het Zuiden reported that he was known to have been depressed while De Telegraaf said that he had been in an Institution for Nervous Diseases. Schizophrenia has been suggested as a diagnosis.

The fifth incident was reported in the Dutch weekly Panorama (Number 3 of 1991). Simon $K$ had teased Siberian tigers in Amsterdam Zoo by throwing beer bottles and burning matches into their cage. When the tigers came to the bars of the cage he tried to pull their tails. He had been grabbed by the tigers more than once but on 15 October 1990 he was bitten on the arm and 
foot, necessitating surgical intervention. He was found to be an unemployed down and out' living in a ruined wartime bunker in the sand dunes who dumped garbage in the garden and set it alight. The fire brigades were almost his only visitors, although a social worker was involved.

A sixth incident was reported in the same issue of Panorama. In Gelsenkirchen Zoo in Germany a 20-year-old man was reported to have sawn through the iron bars of the lion's enclosure in January 1978 and was eaten by 16 lions. Attempts to obtain further information have been frustrated since this zoo has since closed.

The seventh incident occurred on 12 September 1994 when a man scaled a 7 metre steel fence at London Zoo and jumped into the lion's enclosure carrying a bible. The three lions mauled him before being frightened by the shouts of the keepers who beat sticks on dustbin lids. Eventually marksmen entered the enclosure carrying rifles with tranquilliser darts and live ammunition. The man suffered chest and leg injuries and was flown to hospital by helicopter. On the 26 September the Daily Telegraph reported that he was a Nigerian-born unemployed immigrant who had come to this country four years before. He had discharged himself from hospital the previous night. The Guardian reported that he said that he had been trying to prove he was the Son of God because his pastor would not believe him. In the lion's den he was bitten in the leg by a lion cub and then mauled by the same lion who had mauled Ben Silcock. The Audit Commission Report (HMSO, 1994) said that he had refused treatment after one day in hospital and was not considered to be sufficiently at risk to be compulsorily detained. No alternative treatment or support appears to have been offered.

There has also been a recent report from South Africa (Daily Dispatch 20, 21, 22 and 23 December 1994 and Indaba 22 December 1994.). In East London's Queen's Park Zoo (Cape Province) a 27-year-old man climbed a wall more than 3 metres high with a 5 metre drop into the tiger's cage. The keepers fired shots into the ground and the man asked them to shoot him. He had received multiple, superficial claw wounds to his back and was admitted to hospital. In the afternoon he locked himself in a toilet and police and rescue workers had to break down the door. The psychiatric diagnosis is unclear. One report said it was a suicide bid and that he was receiving "psychiatric care" at Frere Hospital. Two other doctors stated he could not be discharged until "the state of his mind was calm", and that he was "too mentally unstable" for this to be considered.

In Cologne, the Kölner Stadt-Anzeiger of $\mathbf{3 0}$ January 1995 gave an account of how a 27year-old drunken man was mauled by two tigers and sustained injuries to the head and upper body. At midnight he had climbed over a 3 metre high fence and then over the 2 metre high safety fence around the reserve, "to take a short cut." The rescue services shot a $9 \mathrm{~mm}$ bullet into the shoulder of one tiger to make it release the man.

The International Herald Tribune (8 March 1995) reported that the woman fatally injured in a lion's den at the National $\mathrm{ZoO}$ in Washington had been identified as a homeless former mental patient from Arkansas. The 36year-old transient lived in a veterans' shelter in Little Rock until she arrived in Washington just days before her death.

\section{Comment}

These ten stories from London and other parts of the world, with different systems of health care for the mentally ill, illustrate that such unfortunate occurrences are not the result of failure to implement adequate community care policies. Policies may be better or worse in countries where, and at the times when, these incidents have occurred. Such events are regrettable, they may or may not stir public interest in a campaign for improved services but they would not be avoided by a return to care in mental hospitals.

\section{Acknowledgements}

I am indebted to a number of people for advice and help in securing information and translating it. I am particularly grateful to Kate Mechanic of New York, Dr Wolfram Voigtlander formerly of Berlin, Wouter van de Graaf of Amsterdam, Artie van Tuijn of Tilburg, Direktor Gürtler of Gelsenkirchen, Dr Detlef Petry of Maastricht, Christiane Haerlin of Cologne and the Editor of the East London Daily Dispatch.

Douglas Bennett, Emeritus Consultant Psychiatrist, Bethlem Royal and Maudsley Hospitals

Correspondence to 5 Mill Lane, Iffley, Oxford OX4 4EJ 